\title{
Are Interleukins Changing the Way we Treat Depression?
}

\author{
Nimra Akram* \\ Department of Medicine, Dow Medical College, Dow University of Health Sciences, Pakistan
}

Submission: July 09, 2018; Published: July 12, 2018

*Corresponding author: Nimra Akram, Department of Medicine, Dow Medical College, Dow University of Health Sciences, Pakistan; Tel: +923422688793; Email: nimra2796@gmail.com

\section{Abstract}

Depression is an ominous disorder that can affect all age groups even the strong athletes are not immune to this disorder. Given its strong influence on the quality of life, its treatment has gained significant importance. As the years are passing, novel advancements in medicine are targeting biological markers for the treatment of diseases. Interleukins are amongst them and gaining importance for the treatment of depression resistant to standard treatment.

Keywords: Depression; Athletes; Interleukins

Abbrevations: MOAs: Monoamine Oxidase Inhibitors; TCAs: Tricyclic Antidepressants; SSRIs: Selective Serotonin Reuptake Inhibitors

\section{Mini Review}

Major depressive disorder is a common as well as ominous disorder that can affect all age groups. It is characterized by unremitting feelings of sadness and despair which lead to poor social skills and if left untreated can be fatal [1]. The disease stems from interplay between susceptible genes and adverse life events. The monoamine hypothesis of depression proposed that underlying pathophysiological basis of depression is a deficit in concentration of brain norepinephrine, dopamine and/or serotonin whereas mania results from elevated concentrations of monoamines. Neuroendocrine studies have demonstrated chronic HPA axis activation in major depression. The neurotrophic hypothesis of depression posited that depression is accompanied by low levels of brain derived neurotrophic factor and atrophy of neurons in hippocampus [2].

Recent novel studies indicate that the prevalence of depression among athletes is parallel to the general population while some reporting even greater prevalence so athletes who were hitherto considered physically and emotionally strong are also susceptible to depression. Gouttebarge, Frings-Dresen and Sluiter in their study on professional footballers found that the prevalence of depression and anxiety disorders were higher among athletes than the community prevalence rates [3]. Another study published in 2015 suggests that the prevalence of mental disorders in a sample of Australian athletes was akin to the prevalence rates in the general population [4].
Three major classes of antidepressant drugs; monoamine oxidase inhibitors (MOAs), tricyclic antidepressants (TCAs) and selective serotonin reuptake inhibitors (SSRIs), all, albeit through different mechanisms, increase the monoamine transmitter levels within the brain synapses. But emerging data from clinical trials indicated that about $30 \%$ of the patients remained unresponsive to the standard treatment [5]. The cytokine hypothesis of depression may explain some of the underlying causes for treatment resistant-depression. Depressed subjects in comparison with controls had significantly increased levels of

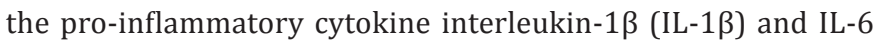
[6].

These pro-inflammatory cytokines might be involved in the development of depression by decreasing the production of monoamines and augmenting HPA axis [7]. In this context, Sirokumab, used for rheumatoid arthritis, may also have antidepressant properties [8]. Inhibition of production of IL-1 by celecoxib resulted in induction of a rapid antidepressant response [9]. Furthermore, recent studies indicated concomitant increase in IL- 6 and decrease in IL-10 in patients suffering from major depression [10]. The antidepressant effect of the antiinflammatory cytokine IL-10 is also supported by studies which indicated that different classes of antidepressants increased IL10 levels upon successful treatment $[11,12]$. 


\section{References}

1. Kessler R, Berglund P, Demler O (2003) The epidemiology of major depressive disorder: Results from the National Comorbidity Survey Replication (NCS-R). JAMA 289(23): 3095-3105.

2. Hasler G (2010) Pathophysiology of Depression: Do we have any solid evidence of interest to clinicians. World Psychiatry 9(3): 151-161.

3. Gouttebarge V, Frings-Dresen MH, Sluiter JK (2015) Mental and psychosocial health among current and former professional footballers. Occup Med 65(3): 190-196.

4. Gulliver A (2015) The mental health of Australian elite athletes. J Sci Med sport 18(3): 255-261.

5. Warden D (2007) The STAR*D Project results: A comprehensive review of findings. Curr Psychiatry Rep 9(6): 449-459.

6. Hannestad J, DellaGioia N, Bloch M (2011) The effect of antidepressant medication treatment on serum levels of inflammatory cytokines: A meta-analysis. Neuropsychopharmacology 36(12): 2452-2459.
7. Catena Dell Osso M (2013) Inflammation serotonin and major depression. Curr Drug Targets 14(5): 571-577.

8. Hsu B (2015) SAT0182 improvement in measures of depressed mood and anhedonia, and fatigue, in a randomized, placebo-controlled, phase 2 study of sirukumab, a human anti-interleukin- 6 antibody, in patients with rheumatoid arthritis. Ann Rheum Dis 74(2): 720-721.

9. Nery F (2008) Celecoxib as an adjunct in the treatment of depressive or mixed episodes of bipolar disorder: A double-blind, randomized, placebo-controlled study. Human Psychopharmacology 23(2): 87-94.

10. Blume J, Douglas S, Evans D (2011) Immune suppression and immune activation in depression. Brain Behav Immun 25(2): 221-229.

11. Kubera M (2001) Prolonged desipramine treatment increases the production of interleukin-10, an anti-inflammatory cytokine, in C57BL/6 mice subjected to the chronic mild stress model of depression. J Affect Disord, 65(2): 171-178.

12. Kenis G, Maes M (2002) Effects of antidepressants on the production of cytokines. Int J Neuropsychopharmacol 5(4): 401-412.

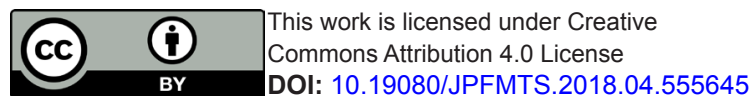

\section{Your next submission with Juniper Publishers} will reach you the below assets

- Quality Editorial service

- Swift Peer Review

- Reprints availability

- E-prints Service

- Manuscript Podcast for convenient understanding

- Global attainment for your research

- Manuscript accessibility in different formats ( Pdf, E-pub, Full Text, Audio)

- Unceasing customer service

Track the below URL for one-step submission https://juniperpublishers.com/online-submission.php 